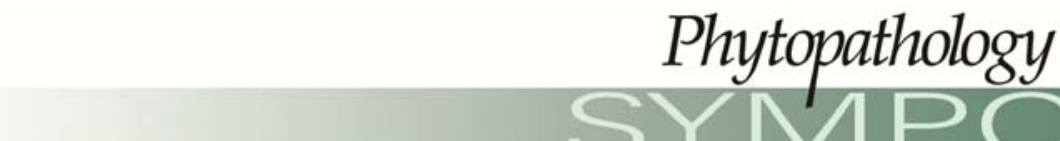

\section{Meta-Analysis to Determine the Effects of Plant Disease Management Measures: Review and Case Studies on Soybean and Apple}

\author{
Henry K. Ngugi, Paul D. Esker, and Harald Scherm \\ First author: Department of Plant Pathology, Pennsylvania State University Fruit Research \& Extension Center, Biglerville 17307; \\ second author: Department of Plant Pathology, University of Wisconsin, Madison 53706; \\ and third author: Department of Plant Pathology, University of Georgia, Athens 30602.
}

ABSTRACT

\begin{abstract}
Ngugi, H. K., Esker, P. D., and Scherm, H. 2011. Meta-analysis to determine the effects of plant disease management measures: Review and case studies on soybean and apple. Phytopathology 101:31-41.

The continuing exponential increase in scientific knowledge, the growing availability of large databases containing raw or partially annotated information, and the increased need to document impacts of large-scale research and funding programs provide a great incentive for integrating and adding value to previously published (or unpublished) research through quantitative synthesis. Meta-analysis has become the standard for quantitative evidence synthesis in many disciplines, offering a broadly accepted and statistically powerful framework for estimating the magnitude, consistency, and homogeneity of the effect of interest across studies. Here, we review previous and current uses of meta-analysis in plant pathology with a focus on applications in epidemiology and disease management. About a dozen formal meta-analyses have been published in the plant pathological literature in the past decade, and several more are currently in progress. Three broad research questions have been addressed, the most common being the comparative efficacy of chemical treatments for managing disease and reducing yield loss across environments. The second most common application has been
\end{abstract}

the quantification of relationships between disease intensity and yield, or between different measures of disease, across studies. Lastly, metaanalysis has been applied to assess factors affecting pathogenbiocontrol agent interactions or the effectiveness of biological control of plant disease or weeds. In recent years, fixed-effects meta-analysis has been largely replaced by random- (or mixed-) effects analysis owing to the statistical benefits associated with the latter and the wider availability of computer software to conduct these analyses. Another recent trend has been the more common use of multivariate meta-analysis or meta-regression to analyze the impacts of study-level independent variables (moderator variables) on the response of interest. The application of meta-analysis to practical problems in epidemiology and disease management is illustrated with case studies from our work on Phakopsora pachyrhizi on soybean and Erwinia amylovora on apple. We show that although meta-analyses are often used to corroborate and validate general conclusions drawn from more traditional, qualitative reviews, they can also reveal new patterns and interpretations not obvious from individual studies.

Additional keywords: chemical control, fire blight, soybean rust, systemic acquired resistance.
Botanical epidemiology is both a concept- and a data-driven discipline. As such, the quantitative review of primary research has a long and rich history in epidemiological investigations, beginning long before the statistical methodology now known as meta-analysis emerged. The most prominent early example is the work of Vanderplank (57), who developed his unifying theory for the mathematical analysis of epidemics largely based on primary data published by others. Indeed, Vanderplank considered himself foremost a "re-viewer of evidence" whose specialty was "to look

Corresponding author: H. Scherm; E-mail address: scherm@uga.edu

doi:10.1094/PHYTO-03-10-0068

(C) 2011 The American Phytopathological Society at published data, assess them, and see how they fit together" (58). The seminal impact of his power to synthesize and discover new patterns and interpretations still reverberates in our research and teaching today.

Given the continuing exponential increase in scientific knowledge, the growing availability of large databases containing raw or partially annotated information, the tendency of old knowledge and publications to be overlooked or forgotten, and the increased need to document impacts of large-scale research and funding programs, there is both a greater opportunity and a greater need today than in Vanderplank's era for adding value to previously published (or unpublished) research through quantitative synthesis. A very eloquent case for the need for "great synthesizers" of data and information to advance 21 st century science, technology, 
TABLE 1

Applications of meta-analysis for evidence synthesis in epidemiology and disease management

\begin{tabular}{|c|c|c|c|c|c|c|}
\hline Year & Authors & Research question & $\begin{array}{l}\text { Meta-analysis } \\
\text { model }\end{array}$ & Effect size ${ }^{a}$ & Main moderator variables ${ }^{b}$ & $K^{\mathbf{c}}$ \\
\hline 1999 & $\begin{array}{l}\text { Shaw and } \\
\text { Larson (51) }\end{array}$ & $\begin{array}{l}\text { Yield effects of pre-plant methyl- } \\
\text { bromide fumigation in strawberry }\end{array}$ & Fixed-effects & $\begin{array}{l}\text { Standardized mean } \\
\text { difference }\end{array}$ & Fumigation frequency & 45 \\
\hline 2001 & Borowicz (5) & $\begin{array}{l}\text { Effect of arbuscular mycorrhizae on } \\
\text { plant and soilborne pathogen } \\
\text { growth }\end{array}$ & $\begin{array}{l}\text { Factorial mixed- } \\
\text { effects; vote- } \\
\text { counting }\end{array}$ & $\begin{array}{l}\text { Standardized mean } \\
\text { difference }\end{array}$ & $\begin{array}{l}\text { Pathogenic fungus and nematode } \\
\text { type; soil phosphorus level }\end{array}$ & $\begin{array}{l}68 \text { (MA) } \\
\text { or } 288 \\
\text { (VC) }\end{array}$ \\
\hline 2004 & $\begin{array}{l}\text { Rosenberg et al. } \\
\text { (46) }\end{array}$ & $\begin{array}{l}\text { Relationship between disease } \\
\text { severity and yield loss for two } \\
\text { foliar wheat diseases }\end{array}$ & Fixed-effects & Regression slope & Disease (tan spot vs. leaf rust) & 5 \\
\hline 2005 & Paul et al. (42) & $\begin{array}{l}\text { Relationship between different } \\
\text { Fusarium head blight intensity } \\
\text { measures and DON } \\
\text { concentration in wheat }{ }^{d}\end{array}$ & Random-effects & $\begin{array}{l}\text { Fisher-transformed } \\
\text { correlation } \\
\text { coefficient }\end{array}$ & $\begin{array}{l}\text { Wheat type; study location; } \\
\text { study type (cultivar vs. } \\
\text { fungicide test) }\end{array}$ & 163 \\
\hline 2005 & $\begin{array}{l}\text { Stiling and } \\
\text { Cornelissen } \\
(54)\end{array}$ & $\begin{array}{l}\text { Effectiveness of biocontrol against } \\
\text { herbivores and weeds }\end{array}$ & Mixed-effects & $\begin{array}{l}\text { log-transformed } \\
\text { response ratio }\end{array}$ & $\begin{array}{l}\text { Biocontrol agent type, taxon, } \\
\text { and feeding guilt; host- } \\
\text { specificity (generalist vs. } \\
\text { specialist); target pest }\end{array}$ & 145 \\
\hline 2006 & $\begin{array}{l}\text { Ojiambo and } \\
\text { Scherm (36) }\end{array}$ & $\begin{array}{l}\text { Effectiveness of biocontrol against } \\
\text { plant disease }\end{array}$ & Fixed-effects & $\begin{array}{l}\text { Standardized mean } \\
\text { difference }\end{array}$ & $\begin{array}{l}\text { Various biological and application- } \\
\text { oriented factors }\end{array}$ & 53 \\
\hline 2006 & Paul et al. (43) & $\begin{array}{l}\text { Effects of study variables on } \\
\text { relationship between Fusarium } \\
\text { head blight intensity and DON } \\
\text { concentration in wheat }{ }^{d}\end{array}$ & Random-effects & $\begin{array}{l}\text { Regression slope } \\
\text { and intercept }\end{array}$ & Wheat type; study location & 126 \\
\hline 2006 & $\begin{array}{l}\text { Shah and Dillard } \\
\quad(50)\end{array}$ & $\begin{array}{l}\text { Relationship between rust severity } \\
\text { and yield loss in sweet corn }\end{array}$ & $\begin{array}{l}\text { Random-effects } \\
\text { meta- } \\
\text { regression }\end{array}$ & Regression slope & $\begin{array}{l}\text { State; year; hybrid; endosperm } \\
\text { type; kernel color; min. and } \\
\text { max. disease severity; severity } \\
\text { range; time between final dis- } \\
\text { ease assessment and harvest }\end{array}$ & $14-20$ \\
\hline 2007 & Morris et al. (31) & $\begin{array}{l}\text { Interactive effects of pests and } \\
\text { beneficials on plant performance }\end{array}$ & $\begin{array}{l}\text { Factorial mixed- } \\
\text { effects }\end{array}$ & $\begin{array}{l}\text { Log-transformed } \\
\text { response ratio }\end{array}$ & Various biological factors ${ }^{e}$ & 160 \\
\hline 2007 & Paul et al. (40) & $\begin{array}{l}\text { Efficacy of tebuconazole in reducing } \\
\text { Fusarium head blight and DON } \\
\text { contamination in wheat }^{d}\end{array}$ & $\begin{array}{l}\text { Random and } \\
\text { mixed-effects }\end{array}$ & $\begin{array}{l}\text { Log-transformed } \\
\text { response ratio }\end{array}$ & Wheat type & $101-139$ \\
\hline 2008 & Paul et al. (41) & $\begin{array}{l}\text { Efficacy of triazole fungicides in } \\
\text { reducing Fusarium head blight and } \\
\text { DON contamination in wheat }{ }^{d}\end{array}$ & $\begin{array}{l}\text { Multivariate } \\
\text { random- } \\
\text { effects }\end{array}$ & $\begin{array}{l}\text { Log-transformed } \\
\text { response ratio }\end{array}$ & $\begin{array}{l}\text { Wheat type; disease and toxin } \\
\text { levels in the untreated check }\end{array}$ & $45-152$ \\
\hline 2009 & $\begin{array}{l}\text { Scherm et al. } \\
\text { (48) }\end{array}$ & $\begin{array}{l}\text { Efficacy of fungicides in reducing } \\
\text { rust severity and yield loss in } \\
\text { soybean }\end{array}$ & Nonparametric & Response ratio & $\begin{array}{l}\text { Disease severity class; yield gain } \\
\text { class; active ingredient; num- } \\
\text { ber of applications; disease } \\
\text { severity at time of application }\end{array}$ & 71 \\
\hline 2010 & $\begin{array}{l}\text { Ojiambo et al. } \\
\text { (35) }\end{array}$ & $\begin{array}{l}\text { Efficacy of fungicides in managing } \\
\text { downy mildew in cucurbits }\end{array}$ & $\begin{array}{l}\text { Fixed, random, } \\
\text { and mixed- } \\
\text { effects }\end{array}$ & $\begin{array}{l}\text { Log-transformed } \\
\text { standardized mean } \\
\text { difference }\end{array}$ & $\begin{array}{l}\text { Cucurbit type; fungicide; year; } \\
\text { disease pressure; number of } \\
\text { applications }\end{array}$ & 105 \\
\hline 2010 & Paul et al. (39) & $\begin{array}{l}\text { Yield effects of triazole fungicide } \\
\text { applications against Fusarium } \\
\text { head blight in wheat }\end{array}$ & $\begin{array}{l}\text { Multivariate } \\
\text { random- } \\
\text { effects }\end{array}$ & Mean difference & $\begin{array}{l}\text { Disease pressure (head blight } \\
\text { index in untreated check); } \\
\text { wheat type }\end{array}$ & $47-136$ \\
\hline$\cdots$ & $\begin{array}{l}\text { E. M. Del Ponte } \\
\text { et al. (unpub- } \\
\text { lished data) }\end{array}$ & $\begin{array}{l}\text { Relationship between rust severity } \\
\text { and yield loss in soybean }\end{array}$ & $\begin{array}{l}\text { Random-effects } \\
\text { meta- } \\
\text { regression }\end{array}$ & $\begin{array}{l}\text { Percent yield loss as } \\
\text { estimated from } \\
\text { regression model }\end{array}$ & $\begin{array}{l}\text { Location; year; rust severity class; } \\
\text { cultivar maturity class; soybean } \\
\text { yield class }\end{array}$ & 39 \\
\hline$\cdots$ & $\begin{array}{l}\text { H. K. Ngugi et al. } \\
\text { (unpublished } \\
\text { data) }\end{array}$ & $\begin{array}{l}\text { Efficacy of antibiotics, biocontrol } \\
\text { agents, and resistance inducers } \\
\text { against fire blight in apple }\end{array}$ & $\begin{array}{l}\text { Multivariate } \\
\text { random- } \\
\text { effects }\end{array}$ & $\begin{array}{l}\text { Log-transformed } \\
\text { response ratio }\end{array}$ & $\begin{array}{l}\text { Cultivar; disease pressure; } \\
\text { products used alone or in } \\
\text { combination }\end{array}$ & $57-61$ \\
\hline
\end{tabular}

a Common metric for the dependent variable across studies.

b Study characteristics (independent variables) that are considered either via univariate or multivariate meta-analysis, or by subdividing the set of studies into groups corresponding to the study characteristics and conducting the meta-analysis separately for each subgroup.

c $K=$ number of studies included in vote-counting (VC) or meta-analysis (MA).

d DON = deoxynivalenol.

e Factors included study environment (greenhouse versus field), plant type (perennial versus annual), disease type (soilborne versus aerial), pathogen and biocontrol agent type (fungal versus bacterial and $r$ versus $K$-selected), and disease pressure class (based on disease intensity in the untreated check). In addition, studies employing Bacillus spp. as biocontrol agents were compared with all other studies.

f Factors included study environment (greenhouse versus field), plant type (perennial versus herbaceous, crop versus noncrop), pest type (herbivore versus pathogen), beneficial type (pollinator, mycorrhizal fungus, or bacterium), and pest-beneficial combination (two pest species, pest + beneficial, or two beneficial species). 
and commerce has been made by futurists such as Pink (44) and Friedman (10).

There are various ways of combining and summarizing results from prior, independent studies, and important papers that use quantitative approaches other than meta-analysis for evidence synthesis continue to be published in the plant pathological literature $(3,18,30,63)$. Nevertheless, as pointed out in the companion paper by Madden and Paul (24), the advantages of meta-analysis in offering a standardized, broadly accepted, and statistically powerful framework for estimating the magnitude, consistency, and homogeneity of the effect of interest across studies provide a great incentive for the wider application of this particular methodology in plant pathology. The hallmarks of meta-analysis compared with other quantitative methods of evidence synthesis are (i) the calculation of a common metric (effect size) for each included study as the dependent variable and (ii) the explicit accounting for the reliability of each study by weighting its effect size by the inverse of the residual (error) variance. That is, studies with high variance are given lower weights in the analysis, whereas those with low variance (considered more reliable) are given higher weights $(24,37,46)$.

It should be noted that some authors use the term meta-analysis more loosely to include any quantitative synthesis or joint analysis of previously generated data. In contrast, consistent with Madden and Paul (24), we apply a more rigorous, statistically based definition of meta-analysis, considering only analyses based on a weighted effect size calculated across independently conducted studies. Furthermore, we exclude from our review socalled quantitative trait loci (QTL) meta-analyses in which previous information on the position of QTL is combined statistically and mapped onto a host plant or pathogen genetic map with the goal of validating independently published QTL and estimating their chromosomal location more precisely $(11,13,61)$. The number of QTL meta-analyses focusing on the corroboration and consensus-mapping of resistance genes or QTL has increased rapidly during the past few years $(2,12,21,22,52,64)$, but since such analyses address a very different set of research questions than conventional meta-analyses of treatment effects or relationships between different measures of disease, they will not be discussed further here.

\section{SOME APPLICATIONS OF META-ANALYSIS IN PLANT PATHOLOGY}

A detailed example. The first formal meta-analysis in plant pathology was published in 1999 by Shaw and Larson (51), who synthesized data from 45 field studies in California to quantify the effect on strawberry yield of pre-plant soil fumigation with mixtures of methyl-bromide + chloropicrin compared with several chemical alternatives (Table 1). The goal of the analysis was to document the benefit of fumigation in the annual strawberry production system in the face of the regulatory phase-out of methylbromide, based on a decade of largely unpublished field trials during the late 1980s and 1990s. Primary data were contributed by collaborators conducting field trials in the three main strawberry production areas of California and represented "a reasonably complete array of those studies conducted to test fumigation alternatives by public sector researchers between 1987 and 1997" (51). Each included study typically was comprised of a nonfumigated check, a methyl-bromide + chloropicrin standard, and one or more chemical alternatives. For each study, an effect size was calculated as the standardized mean difference $(d)$ in yield between the treatment group (either the methyl-bromide treatment or one of its alternatives) and the nonfumigated check:

$$
d=\frac{\bar{y}_{T}-\bar{y}_{C}}{\sqrt{V}}
$$

where $\bar{y}_{T}$ and $\bar{y}_{C}$ are the means (across replicates) of the treatment and check yields, respectively, and $\sqrt{V}$ is the pooled withingroup standard deviation of the particular study. Here, a positive $d$ value indicates a greater yield in the treatment group than in the check. The effect sizes were subjected to fixed-effects metaanalysis to determine the overall magnitude of the methyl-bromide yield response and to compare it with that of chloropicrin alone, metam sodium, and dichloropropene + chloropicrin.

The results of this synthesis of the first decade of methylbromide alternatives research showed that methyl-bromide + chloropicrin significantly and consistently increased strawberry yield compared with chloropicrin alone (by 9.6\%), dichloropropene + chloropicrin $(14.4 \%)$, metam sodium $(29.8 \%)$, and the nonfumigated check $(94.4 \%)$. When fumigation cycle was included as a moderator variable (i.e., studies were subdivided for analysis into three groups based on how many years ago the last previous methyl-bromide + chloropicrin application was made), yield increases due to fumigation compared with the nonfumigated check were 59.2, 100.2, and $148.4 \%$ for the first, second, and third nonfumigated cycle, respectively. In other words, the more annual methyl-bromide + chloropicrin applications were omitted, the greater the relative yield response to the next fumigation. The authors concluded that at the time the study was published (1999), there was no economically viable substitute for standard pre-plant fumigation with methyl-bromide + chloropicrin in annual strawberry production (51). It would be interesting to conduct a similar meta-analysis today, 10 years later, focusing on data generated during the second decade of intensive methyl-bromides alternatives research which resulted primarily from the U.S. Department of Agriculture's Methyl-Bromide Alternatives grant program (initiated in 2000). Given the broader and more integrated focus of the recent methyl-bromide alternatives research on cultural and biological approaches combined with second-generation chemical alternatives (49), the overall conclusions may well turn out differently.

The analysis by Shaw and Larson (51) was highlighted here in detail not only because it was the first published meta-analysis in plant pathology, but also because it had several attributes for which meta-analysis is generally most useful: (i) it dealt with a controversial issue with important economic and policy implications, hence the need for an objective synthesis; (ii) a relatively large database of prior studies was available for analysis (as a result of the accelerated research into methyl-bromide alternatives following the passage of the Montreal Protocol in 1987); (iii) there was some level of standardization among the studies included in the analysis in terms of how treatments were applied and effect (yield response) evaluated, although the individual studies were not identical in design; (iv) a consistent protocol was applied for deciding which studies could be included in the analysis; and (v) it included a limited number of biologically important study-level moderator variables to be explored by subgroup analysis.

Only about a dozen meta-analyses have appeared in the plant pathological literature since the first such synthesis was published in 1999, but several more are currently in progress (Table 1). Three broad research questions have been addressed in these analyses, the most common being the comparative efficacy of chemical treatments for managing disease and reducing yield loss across environments $(35,39-41,48,51)$. The second most common application has been the quantification of relationships between disease intensity and yield, or between different disease variables, across studies $(8,42,43,46,50)$. Lastly, several authors have used meta-analysis to assess factors affecting pathogen-biocontrol agent interactions or the effectiveness of biological control of plant disease or weeds $(5,27,31,36,54)$.

Effectiveness of chemical control. Meta-analyses of chemical control efficacy have been applied to quantify yield effects of 
methyl-bromide soil fumigation in strawberry (51), reduction of Fusarium head blight intensity and associated mycotoxin contamination and yield loss in wheat in response to triazole fungicide application (39-41), fungicidal suppression of soybean rust and associated yield loss (48), efficacy of different fungicide groups against cucurbit downy mildew (35), and performance of antibiotics and resistance inducers against fire blight in apple (27; H. K. Ngugi, unpublished data). With few exceptions (Table 1), most of these analyses utilized log-transformed response ratios or standardized mean differences (in disease intensity or yield) as effect sizes to be analyzed, given their statistically favorable properties $(14,24)$. In addition to calculating an overall (weighted across studies) effect size for the efficacy of a given chemical or chemical group, and determining whether this effect size is significantly better than an untreated check or some chemical standard, the most useful aspect of chemical control meta-analyses is the exploration of the impact of moderator variables (also called study variables) on control efficacy. These moderator variables arise from the fact that the individual studies comprising the meta-analysis have been conducted in different environments, often involving variations in experimental protocol. Examples include host type (e.g., spring versus winter wheat for Fusarium head blight or cucurbit species for downy mildew), year, study region or state, disease pressure, fungicide class or active ingredient, number of applications, and amount of disease present at the time of application (Table 1). Moderator variables can be considered either by stratifying the set of studies into groups corresponding to study characteristics and conducting the metaanalysis separately for each subgroup, or by applying univariate meta-analysis, an approach analogous to analysis of variance (ANOVA) where groups are regarded as though they were treatments in a one-way ANOVA and the mean effect size estimated for each group. If one is interested in the effects of multiple treatments on a single response or multiple responses to a single treatment, then a multivariate meta-analysis is the most effective option $(24,39,41,59)$. This approach allows one to estimate all the effects or responses in a single analysis as opposed to having to run a separate analysis for each treatment/response. An example of a univariate meta-analysis to determine the effects of biological and application-oriented moderator variables on fungicide efficacy (48) is reviewed in more detail below as part of the soybean rust case study.

Effectiveness of biological control. Conceptually, metaanalyses summarizing the efficacy of biological control are similar to those of chemical control, with one important difference: whereas most chemical control meta-analyses have been based on highly standardized studies such as uniform fungicide trials (39$41,48,51)$, the biocontrol meta-analyses published to date $(5,31$, $36,54)$ have utilized a much more heterogeneous database, comprising studies conducted on different host plant species, with different pathogen-biocontrol agent combinations, and in very different environments (e.g., field versus greenhouse). One advantage of such a broad approach is the ability to ask more fundamental questions; for example, is biocontrol really effective in reducing disease across a wide range of pathosystems? How do life histories of the pathogen, the biocontrol agent, and the host affect success or failure of biological control? Is biocontrol more effective against soilborne diseases versus aerial diseases or against one pathogen group than another? Is it true that biocontrol is inherently more successful in the greenhouse than in the field? And so on. On the other hand, such heterogeneity increases the risk that the individual studies may be too dissimilar to be combined in a meaningful way, i.e., the "apples and oranges" conundrum discussed by Madden and Paul (24). Clearly, deciding where to draw the line between generality and specificity can be a major challenge when designing a meta-analysis.
Taken together, the biocontrol meta-analyses summarized in Table 1 showed that biological control is effective overall (i.e., significantly reduces disease, suppresses weeds, or improves host plant growth), although results from individual studies included in the analyses often were inconsistent. More detailed examination of moderator variables also revealed significant interactions between pathogen and biocontrol agent type on biocontrol efficacy. For example, fungal and bacterial biocontrol agents with life history traits typical of $r$-selected organisms (having short generation times and large numbers of short-lived offspring) were more effective in suppressing disease than those that were not $r$ selected (36); arbuscular mycorrhizae significantly reduced disease caused by fungal pathogens but not by nematodes (5); mycorrhizae were more effective biocontrol agents than rhizosphere bacteria (31); and reduction in weed biomass was better when plant pathogens were applied as biocontrol agents than when herbivores were used (54). Two meta-analyses reported independently that - across a broad range of studies - there was no statistically significant difference in biocontrol efficacy in the greenhouse versus the field $(31,36)$, whereas one analysis found that disease suppression due to biological control was better on annual than on perennial host plants (36). Some of these broad conclusions were surprising, documenting the potential value of meta-analysis in revealing new patterns and interpretations not obvious from the individual studies. This, in turn, can lead to the formulation of new, testable hypotheses about the mechanism(s) underlying the observed moderator variable effects. More detailed results of a meta-analysis to determine biocontrol efficacy on apple (H. K. Ngugi, unpublished data) are discussed below as part of the fire blight case study.

Relationships between disease variables. The third major use of meta-analysis in plant pathology has been in the area of disease intensity-yield loss relationships or, more general, quantifying relationships between different disease variables (Table 1). These analyses differ from those discussed above in that correlation coefficients (transformed or untransformed) or regression slopes and/or intercepts from individual studies, rather than response ratios or standardized mean differences between treatments, are used as effect sizes in the computations. One set of meta-analyses has quantified the magnitude and the strength of the relationship between different measures of Fusarium head blight intensity and concentration of the mycotoxin deoxynivalenol in wheat grain based on results from a large number of uniform fungicide trials $(42,43)$. Other analyses have summarized the relationship between disease severity and yield loss for leaf rust and tan spot in wheat (46) and for common rust on sweet corn destined for freshmarket use versus processing (50). The latter paper applied metaregression (59), a generalization of subgroup analysis, to investigate the effects of a several agronomic moderator variables on the disease-yield loss relationship. Although there was considerable variation among slope estimates from the individual studies, none of the moderator variables included in the analysis (state, year, hybrid, endosperm type, kernel color, minimum and maximum disease severity, severity range, and time between final disease assessment and harvest) reliably accounted for the observed among-study variability. Another example of the use of meta-regression is presented as part of the soybean rust case study below.

Statistical approaches used. The different computational approaches to meta-analysis and their statistical underpinnings are presented in a companion paper (24) and will not be discussed in detail here. However, it is useful in the context of this review to examine some trends on how these approaches have been applied in practice. Only one of the papers summarized in Table 1 has utilized a nonparametric approach to meta-analysis (48), andapart from the example in the companion paper by Mila and Ngugi (27)—Bayesian approaches to meta-analysis have not been 
applied previously in plant pathology. Thus, the large majority of studies have utilized conventional parametric approaches. Among these, fixed-effects meta-analysis has been largely replaced by random- (or mixed-) effects analysis during the past decade, owing to the problematic assumptions of the former (i.e., all studies included in the analysis estimate the same true population effect size) and the wider availability of computer software and algorithms to conduct the latter (59). Fundamentally, the confidence intervals (CIs) and significance tests associated with fixedeffects meta-analysis are valid only if the individual studies included in the analysis are homogeneous, an assumption that often cannot be justified in agricultural research given variable experimental protocols and different environments in which candidate studies are conducted. In such conditions, fixed-effects analysis may overestimate the precision of CIs around differences between groups of moderator variables (15).

Another trend has been the more recent use of multivariate meta-analysis $(39,41)$ or meta-regression $(50)$ to analyze the effects of moderator variables, as opposed to the more commonly used univariate approach (Table 1). Multivariate meta-analysis can result in more accurate and more precise effect size estimates when all treatments are not present in all studies (39), a situation encountered commonly in efficacy trials with fungicides or biocontrol agents. Figure 1 summarizes schematically the most common options for the analysis of moderator variables within the framework of research question, choice of effect size, and overall statistical approach.

\section{CASE STUDY 1: SOYBEAN RUST MANAGEMENT AND YIELD LOSS IN BRAZIL}

Soybean rust, caused by the fungus Phakopsora pachyrhizi, is an economically important disease of soybean and can cause substantial losses, both directly and indirectly. In Brazil, where losses due to the disease have been estimated at $\$ 2$ billion annually (65), there has been a coordinated network of uniform field research trials (hence termed UFTs) to examine the efficacy of foliar fungicides labeled for soybean rust control and applied at standardized times during reproductive development of the crop. The consistency and continuity in reporting the results of these trials makes them well-suited for meta-analysis, allowing im- portant questions to be asked about the relative efficacy of foliar fungicides for soybean rust control and how this disease affects yield.

Previous research from Asia has indicated that older fungicides such as mancozeb and the benzimidazoles suppressed soybean rust, although upwards of three to five applications per growing season were necessary $(53,66)$. In India, Patil and Anahosur (38) found that triazole-based fungicides reduced disease intensity. After arrival of the disease in the Americas and Africa, Miles et al. (28) reported that triazole-based fungicides performed most consistently under low and high disease pressure, and whereas strobilurin fungicides did not necessarily suppress soybean rust most effectively in these trials, yields from plots treated with a strobilurin fungicide often were the highest.

Based on this background information, Scherm et al. (48) performed a meta-analysis of UFTs conducted in nine Brazilian states from 2003/04 through 2006/07 ( $K=73$ trials) to improve the understanding of the efficacy of foliar fungicides for both disease control and yield gain. Two trials were subsequently excluded from the analysis since final disease severity in the untreated check was considered too low $(\leq 5 \%)$ to derive meaningful conclusions about fungicide efficacy. Two dependent variables were defined as the response ratios $(R)$ for disease severity and yield. Additionally, the following moderator variables were considered: (i) disease severity class (low, medium, high); (ii) yield gain class (low, medium, high); (iii) active ingredient (triazole alone, strobilurin alone, triazole and strobilurin applied in combination, and triazole and benzimidazole applied in combination); (iv) number of applications (1 or 2); and (v) disease severity at the time of first fungicide application. The metaanalysis was conducted using nonparametric statistical methods (employing Kruskal-Wallis and signed rank tests) since the distribution of the response ratios for both disease severity and yield (as well as their log-transformed values) did not follow a normal distribution. Deviating from the conventional approach of weighting each trial by the inverse of its error variance, weights in this study were defined as the disease severity in the untreated check for the corresponding trial. This was based on the justification that an experiment carried out under higher disease pressure would provide a more reliable estimate of fungicide efficacy (48).

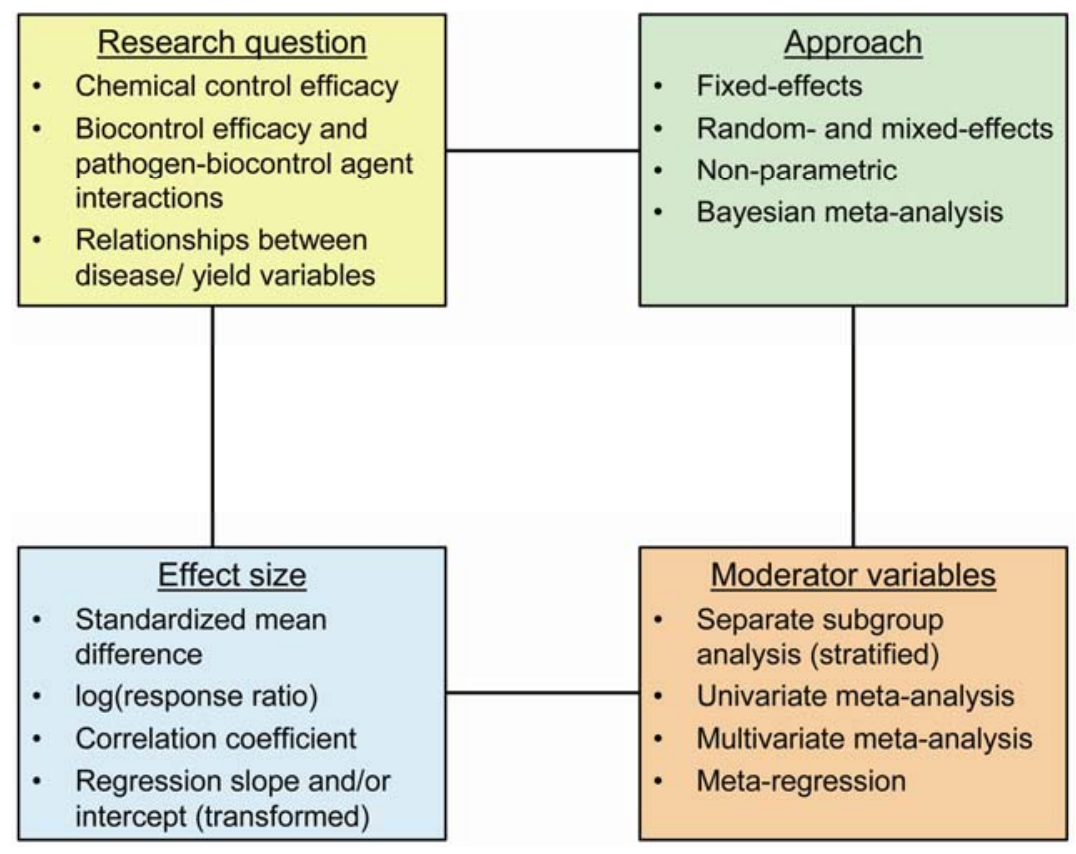

\section{FIGURE 1}

Schematic representation of the components of a typical meta-analysis for evidence synthesis in plant disease epidemiology and management. 
Results showed that using foliar fungicides led to a reduction in soybean rust severity by $\approx 59 \%$ on average (range: -39 to $100 \%$ ), with an associated yield gain of $\approx 44 \%$ (range: -22 to $458 \%$ ) (48). Effect sizes were affected by disease pressure (as measured by disease severity in the untreated check): although there was a better reduction in rust severity when disease pressure was low, the highest relative yield gains were found when disease pressure was high. Very little disease severity $(0.05 \%)$ at the time of application could be tolerated before fungicide efficacy was affected negatively. Similarly, if there was any disease at the time of application, relative yield gain was reduced. For single products, triazoles had better efficacy than strobilurin fungicides, but a larger increase in relative yield gain was found when combinations of triazoles and strobilurins were applied. Lastly, there was a negative correlation between the response ratios for disease severity and yield, meaning that treatments that had good disease control also had increased yield gains, as one would expect. Interestingly, however, two fungicides deviated notably from this general relationship. First, although the combination product flusilazole + carbendazim was highly effective in reducing disease, it showed below-average yield gains. Secondly, myclobutanil, having an intermediate response ratio for disease severity but a very low yield response, also deviated from the overall trend of increasing yields with better disease control. These results again document the value of meta-analysis in revealing patterns not obvious from the individual studies.

In addition to the meta-analysis examining fungicide efficacy (48), the design of the Brazilian UFTs and use of different active ingredients of varying efficacy allowed for the examination of the relationship between yield and soybean rust severity for many of the trials (P. D. Esker, unpublished data). Following methods outlined in Shah and Dillard (50), meta-analysis and metaregression were performed to assess the relationship between disease severity and yield and summarize the nature of this relationship $(8,9)$. For this analysis, there were additional trials available from the 2007/08 growing season, hence the initial database contained 81 trials, of which 39 were retained for analysis based on an examination of raw data and statistical criteria (Fig. 2). These criteria were established to minimize the effect of influential observations and to more effectively study the yield loss relationship as a function of a disease severity gradient. The metaanalysis was conducted in two steps. First, a linear regression analysis was applied to model the relationship between yield and disease severity in each study, from which the expected yield in the absence of disease was estimated. This was then used to determine percent loss as a function of disease severity. A second linear regression model was estimated with the intercept set to zero. Additionally, a random-effects meta-regression model was examined to determine the amount of variation in the second linear regression model that was explained by different moderator variables, including (i) state; (ii) trial year; (iii) rust severity class ( $<50 \%$ or $\geq 50 \%$ ); (iv) cultivar maturity class (late maturity versus others); (v) disease onset timing (before R3 [beginning pod] or after R3); and (vi) soybean yield class $(<2,000 \mathrm{~kg} / \mathrm{ha}, 2,000$ to $4000 \mathrm{~kg} / \mathrm{ha}$, or $>4,000 \mathrm{~kg} / \mathrm{ha}$ ).

Preliminary results from these analyses indicate considerable variation in the relationship between yield loss and soybean rust severity, as slope estimates ranged from 0.31 to 1.81 among studies (P. D. Esker, unpublished data). Yield loss models indicated that for every $1 \%$ increase in soybean rust severity, percent loss varied from 0.6 to $0.8 \%$. Only two moderator variables, timing of disease onset (17\% of the variation) and severity class (16\% of the variation), significantly explained variation in the estimated yield loss relationship. Overall, these results have helped to improve our understanding of yield loss due to soybean rust which, when combined with results from fungicide efficacy trials, will provide better economic information for managing this disease.

\section{CASE STUDY 2: FIRE BLIGHT MANAGEMENT IN THE EASTERN U.S.}

Fire blight, caused by Erwinia amylovora, is the most destructive bacterial disease of Pome fruits. Severe outbreaks are common in the eastern United States, and 2007 was one of the worst fire blight years in recent history in Pennsylvania (32). Sporadic outbreaks affecting young trees grafted on susceptible rootstocks can lead to destruction of entire orchard blocks with considerable losses to growers. One such outbreak in Michigan in 2000 caused the destruction of $\approx 240$ ha of apple orchards with a total loss estimated at over $\$ 42$ million $(23,34)$.
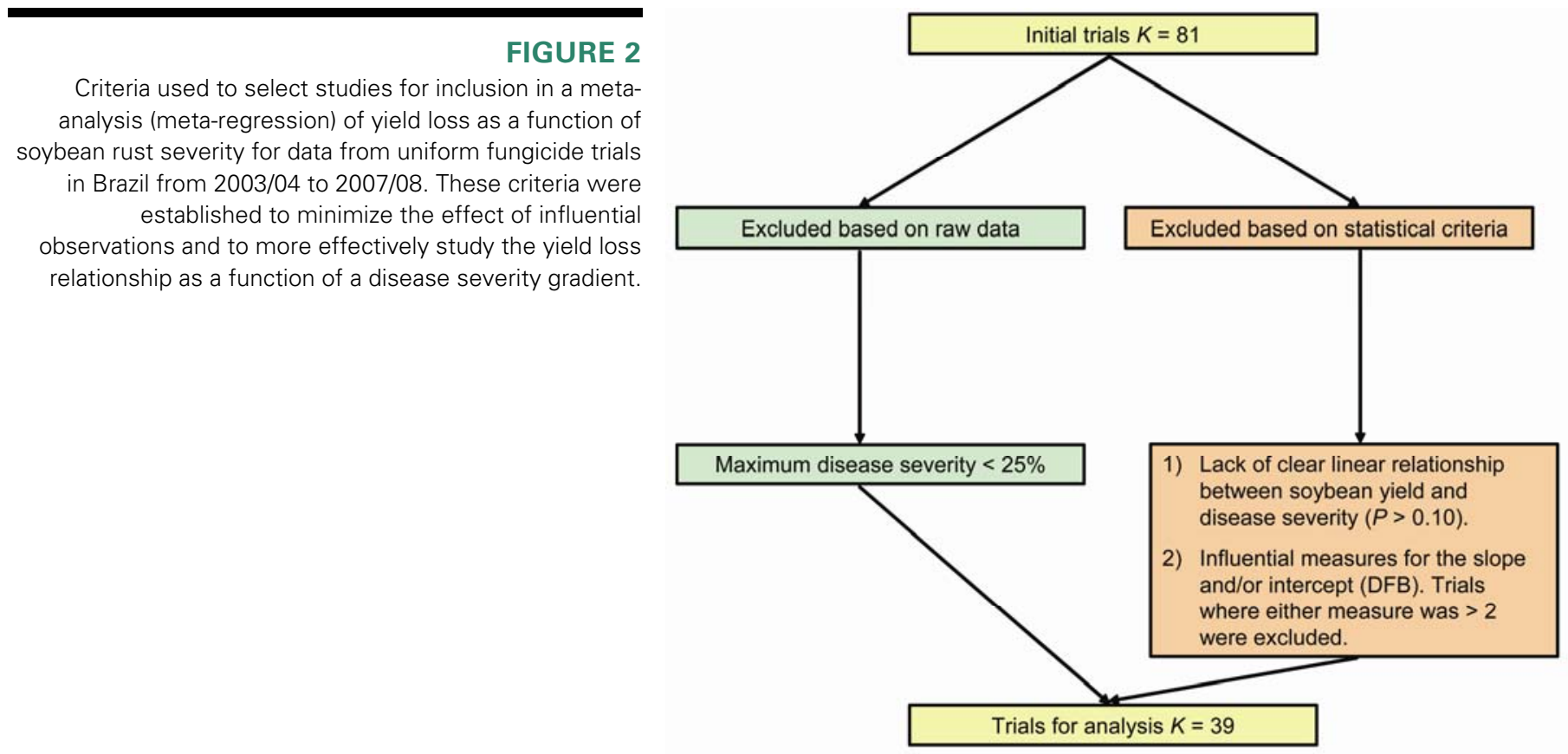
In 1895, M. B. Waite is quoted as having stated "No disease has so completely baffled all attempts to find a satisfactory remedy... notwithstanding the great progress in the last ten years" (56). One only needs to replace "ten" with "hundred" and this statement would still be very valid today. Indeed, despite momentous research efforts and remarkable progress in understanding the biology of the E. amylovora-host interaction, effective tools for disease control are heavily dependent a single compound, the antibiotic streptomycin. Motivated by the development of resistance in E. amylovora populations to streptomycin in most apple production regions in the United States $(7,26,29,47)$, and the potential losses associated with severe outbreaks, the search for alternative products for fire blight management has remained active.

Many products with different active ingredients and disparate modes of action have been evaluated for fire blight control over the last decade. Most of these products can be classified broadly as antibiotics, biological controls, systemic acquired resistance (SAR) inducers, or nutrient supplements. Recent qualitative reviews and descriptive syntheses of the studies evaluating these products concluded that the performance of most of them is inconsistent $(6,55)$. Therefore, the objectives of an ongoing meta- analysis of studies on products evaluated for fire blight control (H. K. Ngugi, unpublished data) are to (i) determine the consistency of performance of products evaluated for fire blight control in the eastern United States over the last decade; (ii) determine and compare the effect sizes for different products; and (iii) explain any inconsistencies in performance across individual studies.

A database consisting of studies on products evaluated for fire blight control between 1999 and 2007 was created by searching the publications Fungicide \& Nematicide Tests, Biological \& Cultural Tests, and Plant Disease Management Reports with the keywords "Erwinia amylovora" and "fire blight". A total of 69 studies was retrieved and screened for inclusion in the metaanalysis based on the general considerations outlined in Box 1 and specific criteria to be presented elsewhere (H. K. Ngugi, unpublished data). Because only $3 \%$ of studies reported a statistic from which a measure of within-study variance (for weighting effect sizes) could be computed, a method for estimating withinstudy variance was developed. This was based on first calculating an estimate of the least significant difference (LSD) for studies that report more than two mean separations. The pooled withinstudy variances $(V)$ for the trials for which the LSD could be

\section{BOX 1}

Criteria for selecting studies for inclusion in a meta-analysis depend on the specific objectives of the analysis $(4,20,62)$. Thus, there is no uniform list of criteria suitable for all types of analyses. However, there are some commonalities, outlined below, that are applicable across a wide range of meta-analyses in plant disease epidemiology and management.

\begin{tabular}{|c|c|}
\hline Criterion & Remarks \\
\hline Type of study & $\begin{array}{l}\text { Identified based on the stated objective of the meta-analysis. For example, if the objective is to determine the } \\
\text { effectiveness of fungicides for control of wheat scab, then efficacy studies on disease suppression by } \\
\text { fungicides should be included. On the other hand, if the objective is to investigate whether reduced tillage has } \\
\text { increased severity of wheat scab, then studies reporting wheat scab severity in fields with or without reduced } \\
\text { tillage practices should be included. }\end{array}$ \\
\hline Type of publication & $\begin{array}{l}\text { There is usually a broad range of publications that potentially could be included in a meta-analysis. For } \\
\text { phytopathological meta-analyses these include, but are not limited to, Plant Disease Management Reports and } \\
\text { its predecessors, uniform multilocation and multiyear trials designed to address specific research questions, } \\
\text { peer-reviewed journals, theses or dissertations, experiment station reports, and many others. In principle, all } \\
\text { studies that meet the established criteria for a given meta-analysis should be included, although it is common to } \\
\text { use accessibility or retrievability as a criterion to restrict the publications to formally published material (20). In } \\
\text { any case, the rationale for restricting the analyses only to certain types of publication must be clearly spelled out } \\
\text { and justified. }\end{array}$ \\
\hline Time frame & $\begin{array}{l}\text { How far back into the literature the meta-analyst should go is dependent on the specific objectives of the study. } \\
\text { For example, a study on the effects of reduced tillage on wheat scab may include data from trials that date back } \\
\text { to the } 1950 \text { s, whereas a study to examine the effectiveness of sterol demethylation inhibitor fungicides on the } \\
\text { same disease can only date back to the } 1980 \text { s when these fungicides became labeled commercially. }\end{array}$ \\
\hline Quality of the study & $\begin{array}{l}\text { The most important consideration should be whether the study provides an unbiased estimate of the measured } \\
\text { effect size. For phytopathological questions, randomized trials that incorporate relevant check treatments will } \\
\text { usually prove superior in this regard. }\end{array}$ \\
\hline Similarity among studies & $\begin{array}{l}\text { Care must be used when considering "similarity" as a criterion for study inclusion in a meta-analysis. A key goal } \\
\text { of meta-analysis is to address broader questions that cannot be addressed by examining only a single study. The } \\
\text { meta-analyst will need to consider the trade-off between narrow criteria for study similarity and the inference } \\
\text { that can be drawn. Borenstein et al. (4) recommend an approach that is either based on (i) narrow criteria to } \\
\text { focus on the summary effect, or (ii) broad criteria to explore the causes for dispersion. }\end{array}$ \\
\hline $\begin{array}{l}\text { Inclusion of relevant } \\
\text { statistics }\end{array}$ & $\begin{array}{l}\text { The two most important statistics are a measure of the effect size and its variance. The companion paper by } \\
\text { Madden and Paul (24) provides an in-depth discussion of appropriate effect sizes for phytopathological studies. }\end{array}$ \\
\hline $\begin{array}{l}\text { Studies that report } \\
\text { different effects }\end{array}$ & $\begin{array}{l}\text { The key consideration is whether the a priori established effect size can be computed from the reported } \\
\text { dependent variable(s) (e.g., use of disease severity in some trials versus area under the disease progress curve in } \\
\text { others). }\end{array}$ \\
\hline
\end{tabular}


derived based on this method were subsequently computed by replacing the actual LSD with the estimated LSD in the formula $(20,40)$ :

$$
V=\frac{n \cdot(L S D / 1.96)^{2}}{2}
$$

where $n$ is the number of replicates of each treatment (usually 4 or 5).

To compute the effect sizes and assess the consistency of products evaluated for fire blight control, studies were grouped into three product-based categories: antibiotics, biological controls, and SAR-inducing products. A separate meta-analysis was carried out for each of these categories. A multivariate randomeffects model was fitted to the data with maximum likelihood $(41,59)$ using the MIXED procedure in SAS (SAS Institute Inc., Cary, NC). Details of model fitting will be given elsewhere (H. K. Ngugi, unpublished data), but briefly, the mean response for each treatment (e.g., disease severity recorded for a given treatment within a study) was used to compute a log-response ratio, $L=$ $\log (R)$. The response ratio $R$ was defined as the disease severity of a given treatment divided by the disease severity of the corresponding untreated check; smaller $R$ values indicate better control efficacy. The mean log-response ratio for each treatment was calculated and back-transformed for data display and presentation. For each treatment, mean percent control was computed as $C=(1-R) \times 100$. The advantage of calculating mean percent disease control is that it has a direct interpretation for evaluating disease management tactics (40).

Figure 3 shows the distribution of back-transformed $R$ values for the three product-based categories. By definition, the lower the value of $R$, the more effective the treatment, and values of $R<$ 0.5 indicate that mean disease level in the treated plots was less than half of that observed in the corresponding untreated check plots. Response ratios varied across the three product-based categories with $R$ values for antibiotic treatments ranging from 0 to 1.13 and with a higher percentage of values being below 0.5 (Fig. 3). In contrast, values of $R$ ranged from 0 to 1.43 and from 0 to 1.44 for biocontrol products and SAR-inducers, respectively. These results provide strong evidence to suggest that among the three product categories, antibiotics were the most effective for fire blight control.

Among the antibiotics, all experimental products evaluated except for copper-based products (which were included in this category although they are general bactericides) provided com- parable levels of fire blight control. Mean percent disease control was $61.7 \%(\mathrm{CI}=55.5$ to $67.0 \%)$ for oxytetracycline, $61.1 \%(\mathrm{CI}=$ 49.3 to $70.2 \%$ ) for gentamicin, $59.8 \%(\mathrm{CI}=46.7$ to $69.6 \%)$ for oxolinic acid, and $59.6 \%$ ( $\mathrm{CI}=40.6$ to $72.5 \%$ ) for kasugamycin (Fig. 4). However, none of these products provided the level of fire blight control obtained with streptomycin, the current standard treatment $(69.8 \%, \mathrm{CI}=61.3$ to $73.7 \%)$. The observation that antibiotics provided the best level of control for fire blight corroborates previous qualitative reviews, and the relative rankings of antibiotic efficacy in our meta-analysis was consistent with the general observations reported previously $(45,60)$.

Most of the biological control treatments provided significant $(<0.01 \leq P \leq 0.0001)$, albeit modest, fire blight suppression relative to the untreated check (Fig. 5). The exception was a treatment that combined products based on Pseudomonas fluorescens and Pantoea agglomerans for which disease suppression was not significantly different from zero $(P=0.093)$, possibly suggesting a negative interaction between these biocontrol bacteria (1). Another key observation was that the effect sizes of the biological controls were significantly lower than those of streptomycin. When applied alone, biocontrol products provided from 23.6 to $31.9 \%$ mean disease control. The best control was noted for treatments consisting of a sequential application of streptomycin with either Pantoea agglomerans $(55.0 \%$ disease reduction) or Bacillus subtilis (53.9\% reduction) (Fig. 5). However, none of these combination treatments performed better than streptomycin alone, although the treatment combining streptomycin and Pantoea agglomerans was similar to streptomycin $(P=$ 0.131 for test of differences in effect sizes; Fig. 4).

These findings, although in agreement with qualitative reviews $(6,55)$, are incongruent with results of tests of the same products conducted in West Coast apple production regions of the United States. For example, disease control levels exceeding 50\% were reported for products based on Pseudomonas fluorescens and Pantoea agglomerans in California, Oregon, and Washington $(16,17,19)$. We hypothesize that these inconsistencies could be due to differences in inoculation methods and/or flower microbial communities between the two production regions.

The SAR-inducers evaluated in the meta-analysis comprised diverse products, including the gibberellic acid inhibitor prohexadione-calcium (Apogee), the harpin protein marketed as Messenger, acibenzolar-S-methyl (Actigard), a plant defense elicitor extracted from brown algae (VacciPlant, also known as Physpe 4),
FIGURE 3

Box-whisker plots showing the distributions of response ratios $(R)$ for antibiotics, biological controls, and systemic acquired resistance (SAR)-inducing products evaluated for control of fire blight on apple in the eastern United States based on reports published in Fungicide \& Nematicide Tests, Biological \& Cultural Tests, and Plant Disease Management

Reports between 2000 and 2008 ( $K=69$ studies). The boxes represent the interquartile range, the line within each box indicates the median, the whiskers correspond to the 5th- and 95th-percentiles, and the dots indicate outliers. The response

ratio is defined as the disease intensity of a given treatment

divided by the disease intensity of the corresponding untreated check; smaller $R$-values indicate better control efficacy. $n=$ number of individual treatments in each category.

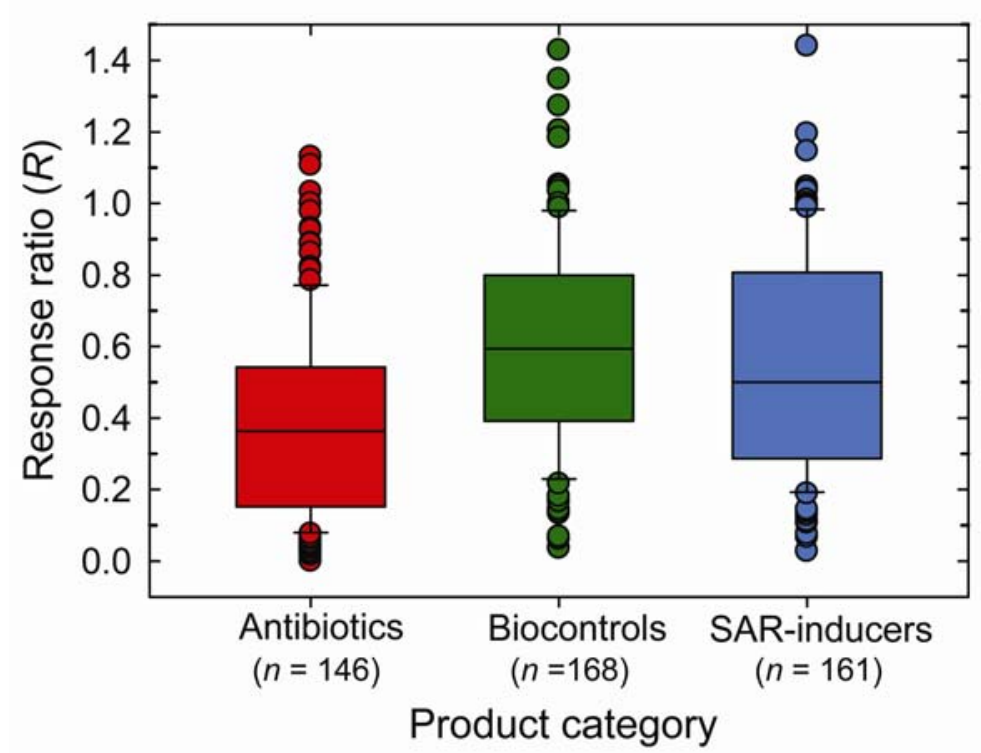


phosphorous acid-containing products (Nutri-Phite, ProPhyt, Phostrol), and the plant growth-stimulating products grouped together as nutrient supplements (Vigor-Cal-Phos and Brotomax). There was considerable variation in the effect sizes of these products when compared with the untreated check. Mean percent disease control ranged from $51.2 \%(\mathrm{CI}=33.1$ to $64.3 \%)$ for phosphorous acid compounds to a low of $6.1 \%$ ( $\mathrm{CI}=-6.6$ to $17.2 \%$ ) for VacciPlant, which did not suppress fire blight significantly (Fig. 6). However, as with the biocontrol treatments, significant improvement in fire blight suppression was noted for treatments consisting of SAR-inducers in combination with the antibiotic streptomycin, for which mean disease control levels were similar to those obtained when using the antibiotic alone (Fig. 6).

Overall, these results indicate that products specifically labeled as SAR-inducers (Messenger, Actigard, and VacciPlant) provided little or no fire blight suppression in the studies included in the meta-analysis. One potential explanation may be the level of inoculum pressure, since it appears that these products performed better in studies relying on natural field inoculum levels than in those utilizing artificial inoculation. For example, acibenzolar- $S$ methyl was reported to provide $>50 \%$ fire blight reduction in tests with naturally occurring inoculum $(25,34)$. Indeed, this conclusion was supported when disease pressure, characterized as 'high' or 'low' (depending on whether or not disease severity in the untreated check was $\geq 65 \%$ ) was included as a moderator variable in the meta-analysis. Consideration of disease pressure as a moderator variable indicated that SAR-products gave inconsistent results whenever evaluated at high disease pressure (H. K. Ngugi, unpublished data).

The significant improvement in efficacy observed when biocontrol and SAR-inducers were applied in combination with streptomycin was not sufficient to qualify as an additive or synergistic interaction and could possibly be attributed to the antibiotic alone. Nevertheless, the improvement may be beneficial in terms of resistance management if use of these products resulted in a reduction in the number of streptomycin applications required to protect blossoms within a season. Indeed, prohexadione calcium, one of the highest-ranked products among the SAR-inducers in the meta-analysis, is routinely recommended as part of an integrated management strategy for fire blight (32-34).

Taken together, results from the meta-analyses of these three product categories indicated that none of the treatments evaluated provides fire blight control equal, or superior, to that obtained when using the antibiotic streptomycin. Given that streptomycin has been used against fire blight since the 1950s $(45,60)$, these results underscore the challenges associated with fire blight management in general-limited effective tools for disease controland confirmed that the situation has not changed much since M.B. White made similar observations in 1895 (56). The study also

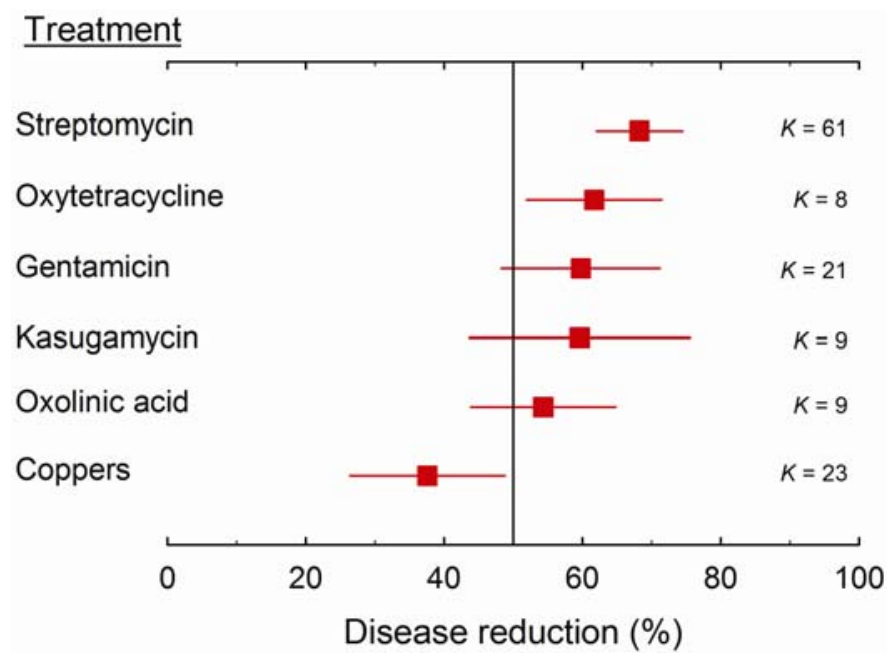

$\underline{\text { Treatment }}$

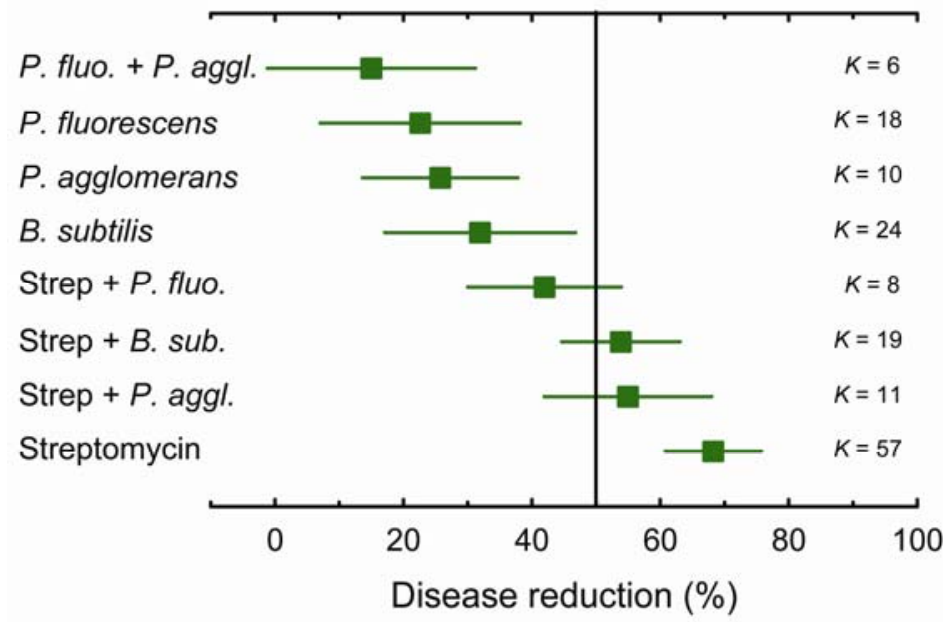

\section{FIGURE 4}

Mean percent disease control and 95\% confidence intervals for antibiotics evaluated for fire blight control in the eastern United States based on reports published in Fungicide \& Nematicide Tests, Biological \& Cultural Tests, and Plant Disease Management Reports from 2000 to 2008. Values were calculated as $C=(1-R) \times 100$, where $C$ is the mean percent disease control for a given treatment relative to the untreated check and $R$ is the back-transformed mean response ratio or confidence interval estimate. The response ratio is defined as the disease intensity of a given treatment divided by the disease intensity of the corresponding untreated check; smaller $R$-values indicate better control efficacy.

\section{FIGURE 5}

Mean percent disease control and 95\% confidence intervals for biological control treatments evaluated for fire blight control in the eastern United States based on reports published in Fungicide \& Nematicide Tests, Biological \& Cultural Tests, and Plant Disease Management Reports from 2000 to 2008. Values were calculated as $C=(1-R) \times 100$, where $C$ is the mean percent disease control for a given treatment relative to the untreated check and $R$ is the back-transformed mean response ratio or confidence interval estimate. The response ratio is defined as the disease intensity of a given treatment divided by the disease intensity of the corresponding untreated check; smaller $R$-values indicate better control efficacy. 


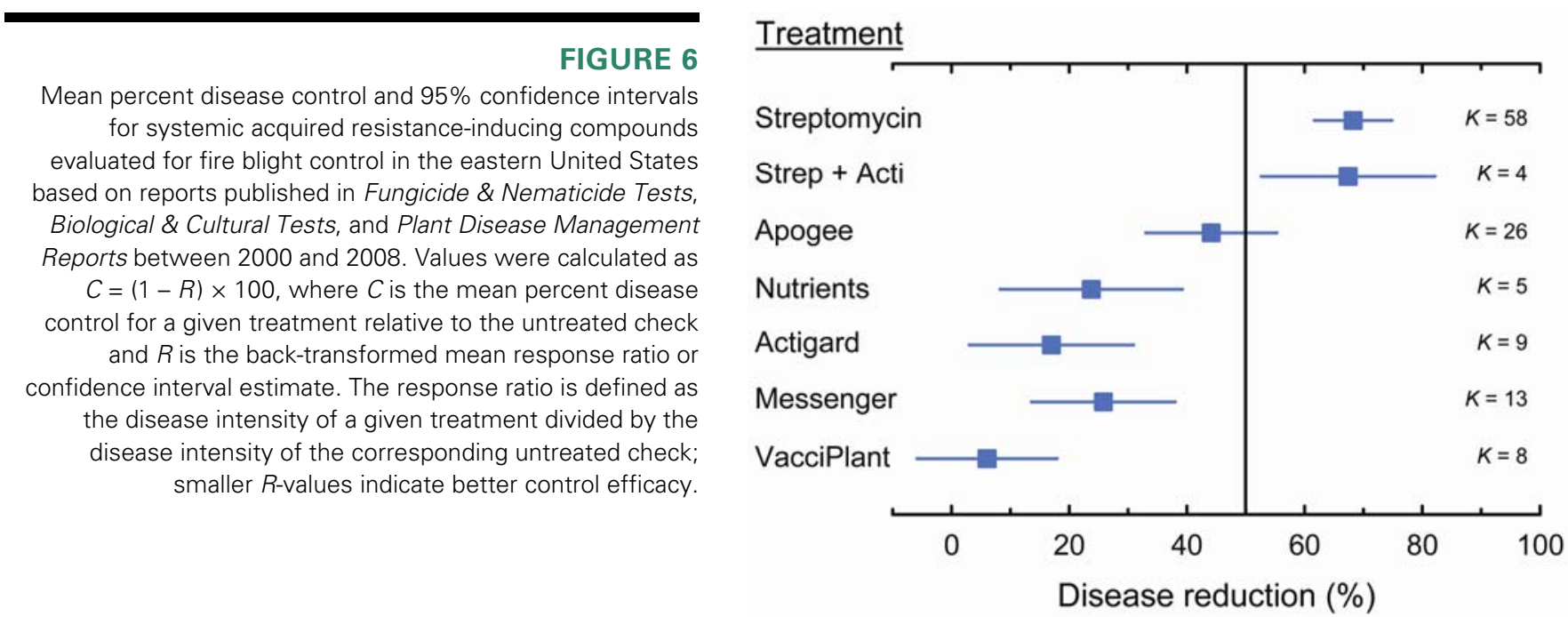

underscores the need for strategies that mitigate the risk of resistance development in populations of E. amylovora in those apple production regions where streptomycin is still effective. We postulate that the likelihood of biocontrol and SAR-inducing products becoming widely adopted for fire blight management in the eastern United States is limited. Because of the magnitude of losses associated with the disease, it is unlikely that growers will rely on products with inconsistent efficacy.

\section{CONCLUSIONS}

Many of the questions addressed in disease management research are complex and require the combined results of studies from multiple years and different environments to resolve. Metaanalysis provides appealing and powerful statistical procedures for combining and jointly analyzing the results from such studies. Since the paper by Shaw and Larson (51), there has been an increasing number of published studies in plant pathology showing that meta-analysis can be an effective tool for addressing questions that range from the very broad (e.g., factors that determine the efficacy of biological controls) to the highly specific (such as the efficacy of a particular pesticide). Based on these considerations, we expect a surge in the use of meta-analysis in the plant pathological literature in the near future. Important limitations that still must be overcome for more widespread application of meta-analysis include the need for more standardized protocols for plant disease management studies (i.e., uniform efficacy trials) and the routine inclusion in publications of relevant statistics (such as LSD and/or coefficient of variation) necessary to weight the effect sizes in the analysis.

\section{ACKNOWLEDGMENTS}

H. K. Ngugi was supported by the State Horticultural Association of Pennsylvania (SHAP).

\section{LITERATURE CITED}

1. Anderson, L. M., Stockwell, V. O., and Loper, J. E. 2004. An extracellular protease of Pseudomonas fluorescens inactivates antibiotics of Pantoea agglomerans. Phytopathology 94:1228-1234.

2. Ballini, E., Morel, J.-B., Droc, G., Price, A., Courtois, B., Notteghem, J.L., and Tharreau, D. 2008. A genome-wide meta-analysis of rice blast resistance genes and quantitative trait loci provides new insights into partial and complete resistance. Mol. Plant-Microbe Interact. 21:859-868.

3. Beyer, M., Klix, M. B., Klink, H., and Verreet, J.-A. 2006. Quantifying the effects of previous crop, tillage, cultivar and triazole fungicides on the deoxynivalenol content of wheat grain: A review. J. Plant Dis. Prot. 113:241-246.

4. Borenstein, M., Hedges, L. V., Higgins, J. P. T., and Rothstein, H. R. 2009. Introduction to Meta-Analysis. Wiley, West Sussex, U.K.

5. Borowicz, V. A. 2001. Do arbuscular mycorrhizal fungi alter plantpathogen relations? Ecology 82:3057-3068.

6. Cooley, D. R. 2006. Are biological controls and resistance activators viable alternatives to streptomycin? Fruit Notes 71(4):12-16.

7. Coyier, D. L., and Covey, R. P. 1975. Tolerance of Erwinia amylovora to streptomycin sulfate in Oregon and Washington. Plant Dis. Rep. 59:849852.

8. Del Ponte, E. M., Maia, A. H., Esker, P. D., and Godoy, C. V. 2009. Metaanalysis of the linear relationship between soybean yield loss and rust severity from uniform fungicide trials. Page 16 in: Proc. 2009 National Soybean Rust Symposium, New Orleans, LA.

9. Esker, P., and Scherm, H. 2009. Effect of foliar fungicides used to control soybean rust. (Abstr.) Phytopathology 99:S162.

10. Friedman, T. L. 2007. The World Is Flat 3.0: A Brief History of the Twenty-First Century. Picador, New York.

11. Goffinet, B., and Gerber, S. 2000. Quantitative trait loci: A meta-analysis. Genetics 155:463-473.

12. Guo, B., Sleper, D. A., Lu, P., Shannon, J. G., Nguyen, H. T., and Arelli, P. R. 2006. QTLs associated with resistance to soybean cyst nematode in soybean: Meta-analysis of QTL locations. Crop Sci. 46:595-602.

13. Hanocq, E., Laperche, A., Jaminon, O., Lainé, A.-L., and Le Gouis, J. 2007. Most significant genome regions involved in the control of earliness traits in bread wheat, as revealed by QTL meta-analysis. Theor. Appl. Genet. 114:569-584.

14. Hedges, L. V., Gurevitch, J., and Curtis, P. S. 1999. The meta-analysis of response ratios in experimental ecology. Ecology 80:1150-1156.

15. Hunter, J. E., and Schmidt, F. L. 2000. Fixed effects vs. random effects meta-analysis models: Implications for cumulative research knowledge. Int. J. Select. Assess. 8:275-292.

16. Johnson, K. B., and Stockwell, V. O. 2000. Biological control. Pages 319337 in: Fire Blight: The Disease and Its Causative Agent, Erwinia amylovora. J. Vanneste, ed. CAB International, Wallingford, U.K.

17. Johnson, K. B., Stockwell, V. O., McLaughlin, M. J., Sugar, D., Loper, J. E., and Roberts, R. G. 1993. Effect of bacterial antagonists on establishment of honey bee-dispersed Erwinia amylovora in pear blossoms and on fire blight control. Phytopathology 83:995-1002.

18. Kranz, J. 2003. Comparative Epidemiology of Plant Diseases. Springer, Berlin.

19. Lindow, S. E., McGourty, G., and Elkins, R. 1996. Interactions of antibiotics with Pseudomonas fluorescens A506 in the control of fire blight and frost injury in pear. Phytopathology 86:841-848.

20. Lipsey, M. W., and Wilson, D. B. 2001. Practical Meta-Analysis. SAGE Publications, Thousand Oaks, CA.

21. Liu, S., Hall, M. D., Griffey, C. A., and McKendry, A. L. 2009. Metaanalysis of QTL associated with Fusarium head blight resistance in wheat. Crop Sci. 49:1955-1968.

22. Löffler, M., Schön, C. C., and Miedaner, T. 2009. Revealing the genetic architecture of FHB resistance in hexaploid wheat (Triticum aestivum L.) 
by QTL meta-analysis. Mol. Breed. 23:473-488.

23. Longstroth, M. 2000. The fire blight epidemic in southwest Michigan 2000. Michigan State University Extension, Van Buren County; published online at http://www.canr.msu.edu/vanburen/fb2000.htm

24. Madden, L. V., and Paul, P. A. 2011. Meta-analysis for evidence synthesis in plant pathology: An overview. Phytopathology 101:16-30.

25. Maxson-Stein, K., He, S.-Y., Hammerschmidt, R., and Jones, A. L. 2002. Effect of treating apple trees with acibenzolar-S-methyl on fire blight and expression of pathogenesis-related protein genes. Plant Dis. 86:785-790.

26. McManus, P. S., and Jones, A. L. 1994. Epidemiology and genetic analysis of streptomycin-resistant Erwinia amylovora from Michigan and evaluation of oxytetracycline for control. Phytopathology 84:627-633.

27. Mila, A. L., and Ngugi, H. K. 2011. A Bayesian approach to meta-analysis of plant pathology studies. Phytopathology 101:42-51.

28. Miles, M. R., Levy, C., Morel, W., Mueller, T., Steinlage, T., van Rij, N., Frederick, R. D., and Hartman, G. L. 2007. International fungicide efficacy trials for the management of soybean rust. Plant Dis. 91:14501458.

29. Miller, T. D., and Schroth, M. N. 1972. Monitoring epiphytic population of Erwinia amylovora on pear with a selective medium. Phytopathology 62:1175-1182.

30. Mitchell, C. E., and Power, A. G. 2003. Release of invasive plants from fungal and viral pathogens. Nature 421:625-627.

31. Morris, W. F., Hufbauer, R. A., Agrawal, A. A., Bever, J. D., Borowicz, V. A., Gilbert, G. S., Maron, J. L., Mitchell, C. E., Parker, I. M., Power, A. G., Torchin, M. E., and Vazquez, D. P. 2007. Direct and interactive effects of enemies and mutualists on plant performance: A meta-analysis. Ecology 88:1021-1029.

32. Ngugi, H. K. 2008. PA fire blight watch for 2008. Fruit Times 27(4):1-2.

33. Norelli, J. L., and Miller, S. S. 2004. Effect of prohexadione-calcium dose level on shoot growth and fire blight in young apple trees. Plant Dis. 88:1099-1106.

34. Norelli, J. L., Jones, A. L., and Aldwinckle, H. S. 2003. Fire blight management in the twenty-first century-using new technologies that enhance host resistance in apple. Plant Dis. 87:756-765.

35. Ojiambo, P. S., Paul, P. A., and Holmes, G. J. 2010. A quantitative review of fungicide efficacy for managing downy mildew in cucurbits. Phytopathology 100:1066-1076.

36. Ojiambo, P. S., and Scherm, H. 2006. Biological and application-oriented factors influencing plant disease suppression by biological control: A meta-analytical review. Phytopathology 96:1168-1174.

37. Olkin, I., and Shaw, D. V. 1995. Meta-analysis and its applications in horticultural science. HortScience 30:1343-1348.

38. Patil, P. V., and Anahosur, K. H. 1998. Control of soybean rust by fungicides. Indian Phytopathol. 51:265-268.

39. Paul, P. A., Hershman, D. E., McMullen, M. P., and Madden, L. V. 2010. Meta-analysis of the effects of triazole-based fungicides on wheat yield and test weight as influenced by Fusarium head blight intensity. Phytopathology 100:160-171.

40. Paul, P. A., Lipps, P. E., Hershman, D. E., McMullen, M. P., Draper, M. A., and Madden, L. V. 2007. A quantitative review of tebuconazole effect on Fusarium head blight and deoxynivalenol content in wheat. Phytopathology 97:211-220.

41. Paul, P. A., Lipps, P. E., Hershman, D. E., McMullen, M. P., Draper, M. A., and Madden, L. V. 2008. Efficacy of triazole-based fungicides for Fusarium head blight and deoxynivalenol control in wheat: A multivariate meta-analysis. Phytopathology 98:999-1011.

42. Paul, P. A., Lipps, P. E., and Madden, L. V. 2005. Relationship between visual estimates of Fusarium head blight intensity and deoxynivalenol accumulation in harvested wheat grain: A meta-analysis. Phytopathology 95:1225-1236.

43. Paul, P. A., Lipps, P. E., and Madden, L. V. 2006. Meta-analysis of regression coefficients for the relationship between Fusarium head blight and deoxynivalenol content of wheat. Phytopathology 96:951-961.
44. Pink, D. H. 2005. A Whole New Mind. Riverhead Books, New York.

45. Psallidas, P. G., and Tsiantos, J. 2000. Chemical control of fire blight. Pages 199-234 in: Fire Blight: The Disease and Its Causative Agent, Erwinia amylovora. J. Vanneste, ed. CAB International, Wallingford, U.K.

46. Rosenberg, M. S., Garrett, K. A., Su, Z., and Bowden, R. L. 2004. Metaanalysis in plant pathology: Synthesizing research results. Phytopathology 94:1013-1017.

47. Russo, N. L., Burr, T. J., Breth, D. I., and Aldwinckle, H. S. 2008. Isolation of streptomycin-resistant isolates of Erwinia amylovora in New York. Plant Dis. 92:714-718.

48. Scherm, H., Christiano, R. S. C., Esker, P. D., Del Ponte, E. M., and Godoy, C. V. 2009. Quantitative review of fungicide efficacy trials for managing soybean rust in Brazil. Crop Prot. 28:774-782.

49. Schneider, S. M., Rosskopf, E. N., Leesch, J. G., Chellemi, D. O., Bull, C. T., and Mazzola, M. 2003. United States Department of AgricultureAgricultural Research Service research on alternatives to methyl bromide: Pre-plant and post-harvest. Pest Manag. Sci. 59:814-826.

50. Shah, D. A., and Dillard, H. R. 2006. Yield loss in sweet corn caused by Puccinia sorghi: A meta-analysis. Plant Dis. 90:1413-1418.

51. Shaw, D. V., and Larson, K. D. 1999. A meta-analysis of strawberry yield response to preplant soil fumigation with combinations of methyl bromide-chloropicrin and four alternative systems. HortScience 34:839845.

52. Shi, L.-Y., Li, X.-H., Hao, Z.-F., Xie, C.-X., Ji, H.-L., Lu, X.-L., Zhang, S., and Pan, G.-T. 2007. Comparative QTL mapping of resistance to gray leaf spot in maize based on bioinformatics. Agric. Sci. China 6:14111419.

53. Sinclair, J. B., and Hartman, G. L. 1995. Management of soybean rust. Pages 6-11 in: Proc. 3rd Soybean Rust Workshop, National Soybean Research Lab, University of Illinois, Urbana-Champaign.

54. Stiling, P., and Cornelissen, T. 2005. What makes a successful biocontrol agent? A meta-analysis of biological control agent performance. Biol. Control 34:236-246.

55. Sundin, G. W., Werner, N. A., Yoder, K. S., and Aldwinckle, H. S. 2009. Field evaluation of biological control of fire blight in the eastern United States. Plant Dis. 93:386-394.

56. Thomson, S. V. 2000. Epidemiology of fire blight. Pages 9-36 in: Fire Blight: The Disease and Its Causative Agent, Erwinia amylovora. J. L. Vanneste, ed. CAB International, Wallingford, U.K.

57. Van der Plank, J. E. 1963. Plant Diseases: Epidemics and Control. Academic Press, New York.

58. Vanderplank, J. E. 1976. Four essays. Annu. Rev. Phytopathol. 14:1-10.

59. van Houwelingen, H. C., Arends, L. R., and Stijnen, T. 2002. Advanced methods in meta-analysis: Multivariate approach and meta-regression. Stat. Med. 21:589-624.

60. van der Zwet, T., and Kiel, H. L. 1979. Fire Blight: A bacterial Disease of Rosaceous Plants. U.S. Dep. Agric. Handbook 510. Washington, DC.

61. Veyrieras, J.-B., Goffinet, B., and Charcosset, A. 2007. MetaQTL: A package of new computational methods for the meta-analysis of QTL mapping experiments. BMC Bioinformatics 8:49.

62. Whitehead, A. 2002. Meta-Analysis of Controlled Clinical Trials. Wiley, West Sussex, U.K.

63. Willocquet, L., Lannou, C., Savary, S., Robert, C., Aubertot, J. N., and Lebard, S. 2008. Simulating multiple pest damage in varying winter wheat production situations. Field Crops Res. 107:12-28.

64. Wisser, R. J., Balint-Kurti, P. J., and Nelson, R. J. 2006. The genetic architecture of disease resistance in maize: A synthesis of published studies. Phytopathology 96:120-129.

65. Yorinori, J. T., Paiva, W. M., Frederick, R. D., Costamilan, L. M., Bertagnolli, P. F., Hartman, G. E., Godoy, C. V., and Nunes, J., Jr. 2005. Epidemics of soybean rust (Phakopsora pachyrhizi) in Brazil and Paraguay from 2001 to 2003. Plant Dis. 89:675-677.

66. Yang, C. Y. 1991. Soybean rust caused by Phakopsora pachyrhizi. First Soybean Rust Workshop, Wuhan, China. 